\title{
Florida Master Beekeeper Program Requirements ${ }^{1}$
}

\author{
James Ellis, Jerry Hayes, Catherine Zettel Nalen, William H. Kern, Ray Zerba, Brad Burbaugh, \\ and Jeanette Klopchin ${ }^{2}$
}

\section{Requirements and General Information (MBP Manual)}

The Master Beekeeper Program (MBP) is a five-year (minimum) beekeeper training and certification program provided by the University of Florida. One must already be a beekeeper to enter the program (please see apprentice requirements, below). Entry into the program is attained by meeting the apprentice requirements and passing the apprentice examinations on exam day. There is no age limit for entry into the program although the examination may be too difficult for children under 12 years of age. All students must enter the program at the Apprentice Beekeeper level and no students are permitted to skip levels.

The program offers four levels of training and advancement: Apprentice Beekeeper, Advanced Beekeeper, Master Beekeeper, and Master Craftsman Beekeeper. All ranks take a minimum of one full year to complete with the exception of Master Level, which takes two years. Opportunities for advancement in the program only occur on exam days, upon meeting all the requirements for the level of advance $\neg$ ment which one is trying to obtain.

The MBP trains and educates beekeepers on new techniques, equipment, potential problems, and tips and tricks to improve their beekeeping skills. Perhaps most importantly, it keeps beekeepers around the state and country connected. MBP participants serve as bee ambassadors to beginning beekeepers, the public, and our community, by teaching and serving as an extension of the UF Honey Bee Research and Extension Laboratory (HBREL).

Examinations are held twice a year and all dates are announced in our quarterly newsletter, the Melitto Files, as well as on our website, www.UFhoneybee.com. Our spring examinations are held the Thursday before the annual UF Bee College, during the University of Florida's spring break (generally, this falls in the first two weeks of March). Our fall examinations are held the Thursday before the annual Florida State Beekeepers Association (FSBA) Convention (generally the last two weeks of October) (www.floridabeekeepers.org).

The training and examination day consists of two parts: material review and examinations. In the morning ( 8 am-12 pm) there are review lectures on important beekeeping topics and in the afternoon there are the written and practical examinations ( $2 \mathrm{pm}-6 \mathrm{pm})$. The exam days are when Advanced, Master, and Master Craftsman Beekeepers submit their required documentation of public service work to the MBP board. Please see Appendix F for examination

All relevant forms are included as addendums at the end of this document.

1. This document is ENY155, one of a series of the Entomology and Nematology Department, UF/IFAS Extension. Original publication date May 2010. Revised October 2013. Visit the EDIS website at http://edis.ifas.ufl.edu.

2. James D. Ellis, associate professor, Entomology and Nematology Department, UF/IFAS Extension, Gainesville, FL 32611; Jerry Hayes, former state bee inspector, Florida Department of Agriculture and Consumer Services, Gainesville, FL 32611; C. M. Zettel Nalen, former Extension assistant, Entomology and Nematology Department, UF/IFAS Extension, Gainesville, FL 32611; William H. Kern, Jr., associate professor, Entomology and Nematology Department, Ft. Lauderdale Research and Education Center, University of Florida, Davie, FL 33314; Ray Zerba, Emeritus Extension agent IV, Clay County Extension, Green Cove Springs, FL 32043; Brad Burbaugh, former Extension agent I, Duval County Extension, Jacksonville, FL 32254; and Jeanette Klopchin, Extension technician, Entomology and Nematology Department, UF/IFAS Extension, Gainesville, FL 32611.

The Institute of Food and Agricultural Sciences (IFAS) is an Equal Opportunity Institution authorized to provide research, educational information and other services only to individuals and institutions that function with non-discrimination with respect to race, creed, color, religion, age, disability, sex, sexual orientation, marital status, national origin, political opinions or affiliations. For more information on obtaining other UF/IFAS Extension publications, contact your county's UF/IFAS Extension office. 
information. Additionally, we hold award ceremonies to recognize all those individuals who have passed the exam at that season's respective conference. In spring we do this at the Bee College awards ceremony and in the fall we do this at the FSBA's banquet dinner. Attendance at these award ceremonies is not required, but is encouraged (information is always announced on www.UFhoneybee.com).

On the next two pages are lists of requirements necessary for a candidate to fulfill in order to achieve each level in the Master Beekeeper Program. It is important that candidates read the requirements closely and make certain that all requirements are met in order to advance in the program. Additional program stipulations (program status, limitations, guidelines, and re-tests) are now listed in Appendix G. Master Beekeeper of the Year requirements and information are listed in Appendix H. Please refer to the summary table on the last page of this document for more information and for MBP board member information.

If at any point you wish to discontinue the program, please contact a board member directly. Please also be sure to keep us informed of your current mailing address, email address, and phone number in case we need to contact you during your enrollment.

\section{I) Apprentice Beekeeper}

A. must be a Florida registered beekeeper or a registered beekeeper in home state, registered either individually or as a member of a family.

B. must own at least one colony of honey bees for at least one full year.

C. must score $70 \%$ or higher on a written examination. The written test can include but is not limited to materials covered during previous UF Bee College lectures and labs, information on the Florida Department of Agriculture and Consumer Services-Division of Plant Industry (FDACSDPI) Apiary website (http://www.freshfromflorida.com/ Agriculture-Industry/Search-by-Industry/ Bees-Apiary/ Apiary-Inspection) or the UF Honey Bee Research and Extension Laboratory (HBREL) website (www.UFhoneybee.com), and material from books/ other literature on the Apprentice Beekeeper reading list (see Appendix E).

D. must score $70 \%$ or higher on a practical examination. The practical examination can include but is not limited to describing the physical parts of a beehive (common terms, not regional nomenclature); lighting and properly using a smoker; recognizing the various stages of brood, different castes of bees, and finding or at least describing the queen; differentiating between brood, pollen, and capped honey; recognizing propolis and describing its functions; describing the layout of a brood nest (placement of honey, pollen, and brood), etc.

\section{II) Advanced Beekeeper}

A. must have held the Apprentice Beekeeper rank at least one full calendar year and have been a practicing beekeeper for at least two years. Also, must be a Florida registered beekeeper or a registered beekeeper in home state.

B. must show proof of having passed six computerized honey bee training modules (with a score of $80 \%$ or higher on each). These will be available at participating county Extension offices throughout Florida, online (at www.UFhoneybee.com, click "Extension" then "Master Beekeeper Program" and scroll down to "modules"), or by request to the UF Honey Bee Research and Extension Laboratory. They will include modules on (1) honey bee pests/parasites/pathogens, (2) honey bee anatomy and behavior, (3) pollination biology, (4) pesticides and honey bees, (5) African honey bees, and (6) honey judging.

C. must score $70 \%$ or higher on a written examination. The written test can include but is not limited to materials covered during previous UF Bee College lectures and labs, information on the FDACS-DPI Apiary website (http://www.freshfromflorida.com/AgricultureIndustry/Searchby-Industry/Bees-Apiary/ApiaryInspection), or the HBREL website (www.UFhoneybee. com), Melitto File articles, and material from books/ other literature on the Advanced Beekeeper reading list (see Appendix E). This examination will cover more information than that required at the Apprentice Beekeeper level. The testable material will closely adhere to information taught in the computerized honey bee training modules ("B" above).

D. must score $70 \%$ or higher on a written examination. The written test can include but is not limited to materials covered during previous UF Bee College lectures and labs, information on the FDACS-DPI Apiary website (http://www.freshfromflorida.com/AgricultureIndustry/Search-by-Industry/Bees-Apiary/Apiary-Inspection), or the UF Honey Bee Research and Extension Laboratory website ((www.UFhoneybee.com), Melitto File articles, and material from books/other literature on 
the Advanced Beekeeper reading list (see Appendix E). This examination will cover more information than that required at the Apprentice Beekeeper level. The testable material will closely adhere to information taught in the computerized honey bee training modules ("B" above).

E. must score $70 \%$ or higher on a practical examination. The practical examination can include but is not limited to: identifying pests, parasites and pathogens; reading pesticide labels and determining which is the safest to use around bees; identifying several beekeeping items; examining honey labels for errors; distinguishing between bees, wasps, hornets, etc.; and identifying anatomical structures of a bee, flower, etc.

F. must perform and be able to document participation in five public service credits (see Appendix A). The Public Service Credit Documentation Form is only a supporting document and should not be the only evidence of a completed PSC. Please see Appendices A and G for documentation guidelines and Addendum 1 for the form.

\section{III) Master Beekeeper}

A. must have held the Apprentice and Advanced Beekeeper ranks one year each and have been a practicing beekeeper for at least three years. Must be a Florida registered beekeeper or a registered beekeeper in home state.

B. must demonstrate/document 10 additional public service credits beyond that required for the Advanced Beekeeper level (see Appendix A). Please see Appendices $A$ and $G$ for documentation guidelines and Addendum 1 for the form.

C. choose and declare major (see Appendix C) and demonstrate/document expertise in 3 of 10 credits within the major. We refer to these as "major credits." Please see Appendix $\mathrm{G}$ for documentation guidelines and Addendums 2 and 3 for the forms.

D. must demonstrate/document expertise in five credits outside the major. We refer to these as "core credits." The core credits can be chosen from Appendix B or students may choose non-overlapping credits from other majors to fulfill core credits. Please see Appendix G for documentation guidelines and Addendum 3 for the form.

E. must score $70 \%$ or higher on a written examination. The written examination can include but is not limited to materials covered during previous UF Bee College lectures and labs, information on the FDACS-DPI Apiary website (http://www.freshfromflorida.com/ Agriculture-Industry/Search-by-Industry/Bees-Apiary/ Apiary-Inspection), the HBREL website (www.UFhoneybee.com), and material from books/ other literature on the earlier reading lists.

\section{IV) Master Craftsman Beekeeper}

A. must have held the Master Beekeeper rank at least two years and have been a beekeeper at least five years. Must be a Florida registered beekeeper or a registered beekeeper in home state.

B. must have 15 additional public service credits beyond that required for a Master Beekeeper (see Appendix A). "Extra" public service credits obtained while certifying for the Master Beekeeper level cannot be applied to the 15 total public service credits needed to achieve Master Craftsman status. Please see appendices A and G for documentation guidelines and Addendum 1 for the form.

C. must satisfy five additional new credits toward declared major for a total of eight "major credits" (three credits having been completed in the Master Beekeeper level). Students changing majors must re-declare the new major with the MBP board or advisors and still satisfy eight total credits toward the new major unless previously acquired credits overlap with the new major. Please see Appendix G for documentation guidelines and Addendum 3 for the form.

D. must demonstrate expertise in eight additional new credits outside declared major (for a total of 13 credits outside major (five credits having been completed in the Master Beekeeper level). We refer to these as "core credits." The core credits can be chosen from Appendix $\mathrm{B}$, or students may choose non-overlapping credits from other majors to fulfill core credits. Please see Appendix Florida Master Beekeeper Program Requirements 4 G for documentation guidelines and Addendum 3 for the form.

E. must demonstrate communication skills (see Appendix D).

F. must pass an oral examination. Nominee is tested by at least three individuals on the review board. The candidate is tested on one specific area of his or her choice (major) as well as on general knowledge of those areas related to honey bees and beekeeping. 
G. must develop and execute a UF (or other university), FDACS-DPI, or USDA-affiliated research project or county Extension affiliated Extension program. We require that you identify an individual within one of these institutions to advise you throughout the project. Master Craftsman candidates will spend a minimum of two years at the Master Level. Please see Appendix I for project/program guidelines.

\section{APPENDIX A}

\section{Public Service Credit Requirements (ADVANCED, MASTER, AND MASTER CRAFTSMAN LEVELS)}

Candidates for the Advanced Beekeeper rank or higher must document a certain number of public service credits. "Public service" is defined as volunteer service or educational activity oriented around bees and beekeeping and conducted for the benefit of the public (non-beekeeping audience). Educational activities in conjunction with commercial ventures generally do not qualify (i.e., selling honey).

One public service credit (PSC) equals a single, documented event of a qualified public service. Multiple repetitions of a particular activity may count, but only if they involve separate events or invitations. For example, two presentations to fifth-grade science classes may qualify as two PSCs but not if they are two successive class periods on the same day to the same audience.

The key to PSCs is adequate documentation of the event. Primary documentation is represented by original media: conference programs, testimonial letters from third parties, newspaper clippings, photographs, or video recordings. Secondary documentation may lack material evidence of the activity, but must at least include a written statement with the title of the event, date, place, time topic, target clientele group and number attended, description of the activity, and its outcome. In general, documentation must be material evidence, in writing; and more detail is better than less. Board members reserve the right to accept or reject documentation during program audits. Candidates for Advanced Beekeeper must present documentation to the Master Beekeeper Program Board prior to taking the written examination. Please see Appendix G for documentation guidelines and Addendum 1 for the form.

The following activities are pre-approved for satisfying PSC requirements. Other activities may be admissible, but candidates are advised to contact program officers about specific cases.

1. Presenting a bee-related lecture or workshop to nonbeekeeping group (youth or adult).

2. Holding office in a local beekeeping association.

3. Assisting members of youth organizations (4-H, Scouts, FFA), etc. with project work.

4. Mentoring a new beekeeper through at least one complete season.

5. Giving a public demonstration on beekeeping topic at fair, festival or similar public event

6. Providing a hive of bees to pollinate a public garden.

7. Establishing and maintaining an observation hive for school or civic group.

8. Becoming an expert contact on bee-related questions for a UF/IFAS County Extension office (see points below).

- Must contact your county agent and the MBP board to offer your expertise.

- Must have scored an average of $80 \%$ on most recent practical and written exams (contact the HBREL for confirmation and we will forward scores to your agent).

- Must be a beekeeper in the county for which you have been appointed an expert contact (counties may have multiple expert contacts).

- Must follow BMPs for keeping European colonies (have an inspector document your participation).

- Must provide a clear channel of communication open to the county, the agent, and the public (e.g., telephone, email, social media, etc).

- Must receive a positive evaluation from Extension agent stating: your dates of service, the value of your performance to the office, and the approximate time you dedicated to position, and any additional comments.

(It may be possible to act as an expert contact for another municipal agency. Appointments are at the discretion of the MBP board and the agency in question.)

\section{APPENDIX B}




\section{Core Credits}

Core Credit Requirements - Advanced Beekeepers must document completion of five credits outside their major before they can be considered for advancement to the Master Beekeeper level. Master Beekeepers must complete an additional eight core credits for a grand total of 13 core credits to qualify for Master Craftsman level. You can choose any of the following credits not in your declared major to fulfill this requirement. You may choose nonoverlapping credits from other majors to fulfill your core credits. A form to document your core credits is located in Addendum 3.

1. Winning first or second place in an authorized competition in extracted honey, comb or cut-comb honey, crystallized (spun or creamed) honey, or beeswax.

2. Publishing an article in a beekeeping publication (excluding newsletters).

3. Publishing an article in a non-beekeeping publication (with at least state-wide distribution).

4. Being recognized as a beekeeping authority in your local area by appearing on radio or television.

5. Documenting training in life-saving treatment of persons suffering from allergic reactions to insect stings.

6. Attending at least three beekeeping meetings (these must be regional, multi-state, national or international).

7. Conducting a program or workshop at a state, regional, national or international meeting or convention.

8. Demonstrating competence in small-scale queen rearing.

9. Completing a course on artificial queen insemination.

10. Acquiring private pesticide applicator's license.

11. Show evidence that you maintain a legally licensed honey processing facility.

12. Participating/volunteering in a beekeeping research or Extension project at an approved institution.

13. Acquiring other certified bee-related training as approved by the MBP board.
14. Serving two or more years as an officer in a bee organization at state level or higher (need not be consecutive nor in the same organization).

15. Documenting culture/maintenance of other bee species (bumble bees, halictids, etc.).

16. Mentoring a beekeeping group in a rural/underprivileged/international community.

17. Acquiring international beekeeping experience with clear, documented benefits to the international group and to Florida.

18. Maintaining a public blog, public journal, or public forum on honey bees. The resource must be informative; science-based, easily accessible, and advertised; and you must be able to show the number of site visits it receives during the year.

19. Volunteering at least 40 hours with a commercial beekeeper or organized university apiary.

${ }^{*}$ Some bee-related activities not listed above may also be determined to fulfill the core credit requirements. Consult the MBP board prior to activity.

\section{APPENDIX C}

\section{Majors and Major Credits}

Major Credit Requirements - Advanced Beekeepers must document completion of three credits within their major before they can be considered for advancement to the Master Beekeeper level. Master Beekeepers must complete an additional five major credits for a grand total of eight major credits to qualify for Master Craftsman level. Beekeepers must be able to document activities - contact the MBP board if you have questions about any of the requirements. Other suggested majors/credits will be considered. A major must be declared to the board before achieving Master Beekeeper status. A form to declare your major is available in Addendum 2. A form to document your major credits is available in Addendum 3.

\section{Diagnosis and treatment of honey bee pests, parasites, and pathogens}

a. Pass (with a score of $70 \%$ or higher) a tutorial on diseases of the honey bee.

b. Pass (with a score of $70 \%$ or higher) a tutorial on pests/parasites of the honey bee. 
c. Present a lecture on bee pests/diseases at state beekeepers meeting or higher.

d. Switch to and document use of IPM (integrated pest management) in personal beekeeping operation.

e. Serve as "local expert" and assist other beekeepers in proper disease/pest diagnosis in their colonies.

f. Acquire a pesticide applicator license.

g. Create reference collection (sterile) of bee pests and diseases.

h. Research and review one pest or disease of honey bees. The review will be published on the HBREL's website. The written review must be accompanied by a slide show presentation.

i. Pass (with a score of $70 \%$ or higher) a practical, hands-on examination of bee pests/diseases.

j. Document attendance at three training workshops on bee pests/diseases.

\section{Pollination ecology and bee botany}

a. Provide pollination services to a gardener (not yourself) or commercial fruit/nut/vegetable grower. (Must document.)

b. Plant a bee-friendly garden in a public area (such as library, town square, etc.).

c. Present a lecture on pollination ecology or bee botany at a state, regional, national, or international beekeepers meeting.

d. Produce a handout to describe local honey production plants and when they bloom for local (county or regional) clientele.

e. Pass (with a score of $70 \%$ or higher) practical examination on bee plants.

f. Research and review one plant that is a major honey production plant in Florida. The review will be published on the Honey Bee Research and Extension Laboratory's website. The written review must be accompanied by a slide show presentation.

g. Become a certified Florida Master Gardener. h. Document training in the identification of pollen present in honey samples.

i. Document work educating the general public about pollinators.

j. Create a museum-quality plant collection of regional honey production plants.

\section{Honey judging}

a. Judge a honey show (state level or higher).

b. Become a certified Welsh Honey Judge at UF Bee College or the Young Harris Institute in Georgia

c. Win first or second place in any category at a state or higher level honey show.

d. Document ability to produce mead.

e. Pass (with a score of $70 \%$ or higher) a practical examination on honey judging.

f. Research and review one type of honey important to the Florida beekeeping industry. The review will be published on the HBREL's website. The written review must be accompanied by a slide show presentation.

g. Educate the public about hive products and their uses at a fair booth or similar event.

h. Show evidence that you maintain a Florida licensed honey house.

i. Document training in the identification of pollen present in honey samples.

j. Document knowledge of honey production/processing and other products of the hive.

\section{Beekeeping for rural development}

a. Document knowledge of alternative methods of queen rearing.

b. Pass (with a score of $70 \%$ or higher) a practical, hands-on examination of bee pests/diseases, including non-chemical control of these disorders. 
c. Document knowledge of honey production/processing and other products of the hive, including value adding theory.

d. Demonstrate proficiency in hive equipment assembly.

e. Demonstrate proficiency in another language

f. Volunteer for a nonprofit charitable organization with agricultural interests such as Winrock International or Partners of the Americas.

g. Become a certified Florida Master Gardener.

h. Pass (with a score of $70 \%$ or higher) a written examination on beekeeping for rural development.

i. Win first or second place in any category at a state or higher level honey show.

j. Document knowledge of pollination ecology, general honey bee biology, and colony management for honey production.

\section{Queen production}

a. Document that you are rearing queens according to FDACS-DPI best management practices (BMPs).

b. Attend an instrumental insemination course.

c. Pass (with a score of $70 \%$ or higher) an examination of mating biology and bee genetics.

d. Research and review alternative queen rearing methods for industry. The review will be published on the Honey Bee Research and Extension Laboratory's website. The written review must be accompanied by a slide show presentation.

e. Volunteer 40 or more hours with a professional queen breeder.

f. Research and review one race of honey bee. The review will be published on the Honey Bee Research and Extension Laboratory's website. The written review must be accompanied by a slideshow presentation.

g. Serve as "local expert" and assist other beekeepers with queen production. Must document service. h. Pass (with a score of $70 \%$ or higher) a tutorial on Africanized honey bees.

i. Document that you have mentored/trained others in the dynamics of queen rearing.

j. Document that you are selecting for resistance traits in your own queen rearing operation.

\section{African honey bees}

a. Document proficiency in FABIS or USDAID bee identification methods.

b. Generate African bee Extension information (presentations, etc.) for a specific target audience (pest control operators, Master Gardeners, etc.).

c. Pass (with a score of $70 \%$ or higher) a tutorial on Africanized honey bees.

d. Pass (with a score of $70 \%$ or higher) an examination of mating biology and bee genetics.

e. Acquire a pesticide applicator license.

f. Document knowledge and participation in colony bait hive service.

g. Document a trip to another area of the world having African bees and your work with the bees in that area.

h. Serve as "local expert" and assist other beekeepers with African bee-related issues.

i. Keep personal bee colonies according to FDACSDPI best management practices (BMPs).

j. Present a lecture on African honey bees at a state, regional, national, or international beekeepers meeting.

\section{Advanced bee husbandry}

a. Switch to and document use of IPM (integrated pest management) in your personal beekeeping operation.

b. Pass (with a score of $70 \%$ or higher) a practical, hands-on examination of bee pests/diseases. 
c. Provide pollination services for a community garden or commercial fruit/nut/vegetable grower.

d. Plant a bee-friendly garden in a public area such as a library or a town square.

e. Become a certified Florida Master Gardener.

f. Document knowledge of honey production/processing and other products of the hive, including value adding theory.

g. Document that you are rearing queens according to FDACS-DPI best management practices (BMPs).

h. Attend an instrumental insemination course.

i. Document proficiency in the Fast Africanized Bee Identification System (FABIS) or USDA-ID.

j. Pass (with a score of $70 \%$ or higher) an examination of mating biology and bee genetics.

\section{Native bee apiculture}

a. Build a native bee nest habitat for a community garden or commercial fruit/nut/vegetable grower.

b. Build a native bee nest habitat in a public area such as a library, a town square, or a school.

c. Present a lecture on (1) native bee diversity or (2) how to create native bee habitats at a state, regional (multi-state), national or international beekeepers meeting.

d. Produce an educational color pamphlet or brochure of local native bees for local (county or region) clientele. (All photos used must be cited and permissions granted by the photographer or copyright holder; a reference list is required.)

e. Pass (with a score of $70 \%$ or higher) a practical examination on bee and wasp identification.

f. Research and produce a review of one species of native Florida bee. The review will be published on the Honey Bee Research and Education Lab's website. The written review must be accompanied by a slideshow presentation.

g. Participate in a university study about native bees and show documentation. h. Conduct a survey using native bee monitoring techniques, and report on the local native bees present in your area with a digital photograph collection of regional bees and wasps complete with an index that provides date/location/identification information for each photo or a museum-quality insect collection of regional bees and wasps complete with collector and species identification labels.

i. Document work to provide native bee education to the general public.

j. Write an article centered around a specific native bee or around native bees in general to be published in a popular journal, magazine or for a website.

\section{Apiculture education}

a. Develop an original, bee-related educational slideshow presentation (check with the MBP board for a topic) for a 45-minute lecture accompanied by a script and a cover page identifying a target audience, and listing accompanying resources and resources for further reading. (All photos used must be cited and permissions granted by the photographer or copyright holder; a reference list is required.)

b. Produce an educational pamphlet or brochure detailing an aspect of beekeeping (extracting honey, building equipment, etc.) for distribution among beekeepers. (All photos used must be cited and permissions granted by the photographer or copyright holder; a reference list is required.)

c. Produce an original educational pamphlet or brochure explaining a bee-related issue for distribution to a specific target audience. (All photos used must be cited and permissions granted by the photographer or copyright holder; a reference list is required.)

d. Write an article about one of the following topics: educa $\neg$ tion using bees, safety and beekeeping, bee-related laws and regulations, bee anatomy and biology, integrated pest management practices for beekeeping, or other approved topic for a popular journal, magazine or newsletter (i.e. Melitto Files).

e. Pass (with a score of $70 \%$ or higher) a module on apiculture education basics. 
f. Document attendance at least three state, regional, national, or international beekeeping seminars (such as the Florida State Beekeepers Association Annual Meeting, the Annual Meeting of the American Beekeeping Federation, etc.).

g. Develop a bee-related teaching module (for beekeepers) accompanied by an evaluation tool (something with which you can judge the success of your teaching module).

h. Provide documentation of successful beekeeping mentorship (i.e., the individual you are mentoring is showing clear progress due to your instruction) via self-created pre- and post-tests, and other evaluations to document growth and progress.

i. Attend one seminar on how to be an effective educator. (Contact the MBP board for assistance finding seminars.)

j. Provide documentation of participation in peer review of Extension presentations by other beekeepers, accompanied by a feedback evaluation form signed by the reviewer, presenter and outreach contact.

\section{APPENDIX D}

\section{Communication Skills}

\section{APPLICABLE FOR MASTER LEVEL ONLY}

- The nominee must present a program at a state-level beekeeper conference. The program may be in the form of a general presentation, workshop, or similar activity.

- The nominee must complete two of the following activities:

1. Prepare and publish an article in a beekeeping journal.

2. Prepare and publish an article on bees or beekeeping in a non-beekeeping publication.

3. Be interviewed on a radio or television program regarding honey bees and/or beekeeping.

4. Be featured in a newspaper article regarding honey bees and/or beekeeping.

\section{APPENDIX E}

\section{Reading Lists}

\section{Suggested Reading List for Apprentice Level} Examinations

\section{Books}

1. Honey Bees and Beekeeping: A Year in the Life of an Apiary, $3^{\text {rd }}$ Edition - Keith Delaplane (2007)

2. The Beekeeper's Handbook, 4th Edition - Diana Sammataro, Alphonse Avitabile, Dewey M. Caron (2011)

3. First Lessons in Beekeeping - Keith Delaplane (2007)

4. The Backyard Beekeeper, Revised and Updated: An Absolute Beginner's Guide to Keeping Bees in Your Yard and Garden - Kim Flottum (2010)

5. Honey Bee Biology and Beekeeping - Dewey Caron (2013)

\section{Periodicals}

1. American Bee Journal

2. Bee Culture

3. Melitto Files Newsletter

Suggested Reading List for Advanced Level Examinations (in addition to those listed for the Apprentice Level Examination)

\section{Books}

1. The Hive and the Honey Bee - Dadant and Sons, Inc. (1992)

2. $\mathrm{ABC} \& \mathrm{XYZ}$ of Bee Culture - A.I. Root (2007)

3. Honey Bee Pests, Predators, and Diseases, $3^{\text {rd }}$ Edition A.I. Root (Morse and Flottum, eds.) (1998)

4. The Biology of the Honey Bee - Mark Winston (1991)

5. Bee Pollination in Agricultural Ecosystems - Rosalind James and Theresa L. Pitts-Singer (2008)

\section{Websites}

1. All "honey bee" entries (search for "honey bee") at: http://edis.ifas.ufl.edu/ 
2. Honey Bee Research and Extension Laboratory website: www.UFhoneybee.com

3. Florida Department of Agriculture and Consumer Services - Division of Plan Industry, Apiary Section website: http://www.freshfromflorida.com/ Agriculture-Industry/Search-by-Industry/Bees-Apiary/ Apiary-Inspection

4. The University of Florida AFBEE website: www.AFBEE.com

5. Honey Bee Parasites, Pests, Predators, and Diseases website https://agdev.anr.udel.edu/maarec/honey-bee-biology/ honey-bee-parasites-pests-predators-and-diseases/

\section{APPENDIX F}

\section{Examinations}

To become Apprentice or Advanced Beekeepers, participants must take a written and practical examination (two hours per exam). Candidates for Master Beekeepers take only a written exam. The written tests may consist of multiple choice, true/false, short answer, and matching questions. The practical tests contain multiple choice, true/ false, and matching questions, but also include identification of hive parts, tools, and diseases/pests of honey bees. Candidates must receive a score of $70 \%$ or higher on both the practical and written examinations to achieve the next level in the program. Passing candidates will receive their certificate of accomplishment at the respective awards ceremony (fall or spring) or by mail. Generally, the apprentice level test will cover the following subject areas: general beekeeping, history of beekeeping, honey bee biology, basic bee anatomy, honey production and products, pests and diseases (common names, causes and treatments), beekeeping equipment use and terminology, and important historical facts (especially people who contributed to the development of beekeeping). Advanced level testing will include all of the apprentice level subjects with the addition of scientific names of pests/diseases and honey bee species, pollination, native bee information and identification, pesticides and Africanized bees. Be sure to review the materials in the reading list provided.

\section{APPENDIX G}

\section{Program Status, Limitations, Presentation and Documentation Guidelines and Re-tests}

\section{PROGRAM STATUS}

1. Active Status - An "active beekeeper" is any Master Beekeeper Program participant who is actively pursuing the next level in the program with no more than two years elapsing before testing to obtain the next level (special exceptions: no more than three years between the Master and Master Craftsman Levels). Anyone wishing to maintain active beekeeper status must complete a yearly activity report. Active beekeepers will receive invitations to MBP-only training events and socials, and emails regarding PSC opportunities.. Only active beekeepers are eligible to receive a Beekeeper of the Year Award.

2. Inactive Status - Any Master Beekeeper Program partici $\neg$ pant who takes longer than two years to test for the next level in the program (three years if testing for the Master Craftsman level) is considered inactive. Participants who fail to submit a yearly activity report will lose their active status. Active beekeepers will receive invitations to $\mathrm{MBP}$ only training events and socials, and emails regarding PSC opportunities. Only active beekeepers are eligible to receive a Beekeeper of the Year Award.

3. Activity Report - Master Beekeeper Program partici $\neg$ pants will now be required to submit a yearly activity report. This report will be part of the documentation used to determine the Master Beekeeper of the Year Award. An activity report should consist of a list of credit-worthy activities completed during the calendar year. Please include the name and a short description of the activity, the date when you performed it, your audience (middle school students, master gardeners, county fair attendees, etc.), and the number of people you reached. Participants are encouraged to use the cover sheets (available in Addendums 4-6) to assist in organizing this information.

These reports will be accepted yearly. The annual deadline is January $31^{\text {st }}$.

\section{LIMITATIONS}

1. The UF Master Beekeeper Program represents a University of Florida Cooperative Extension Service public education program. One should avoid having association with commercial products or implying University of Florida/IFAS Cooperative Extension Service endorsements of any product or place of business. 


\section{PUBLIC SERVICE CREDITS PRESENTATION GUIDELINES}

1. Be punctual, trustworthy, and reliable. Follow through on your commitments and responsibilities. Call if you will be delayed or cannot attend the event. Make a reasonable effort to find a replacement speaker if you are going to miss a commitment.

2. Maintain a friendly, warm, and courteous attitude toward the public.

3. Communicate effectively with clients, staff and fellow Master Beekeeper Program students.

4. Dress appropriately for the volunteer activity in which you are involved.

5. Follow UF/IFAS Extension affirmative action policies which forbid discrimination against anyone because of their race, color, gender, nation of origin, religion, age, disability, sex, sexual orientation, marital status, national origin, political opinions or affiliations.

\section{DOCUMENTATION GUIDELINES}

Advanced level and higher are required to complete public service credits throughout the year and turn in documentation. All documentation is due by noon on exam day. For each credit, present a "Documentation of Public Service Credits Form" and at least one additional piece of evidence that shows you completed the requirements for the credit. All levels must use the appropriate cover sheets to organize and summarize their credits witch are included as addendums 4-6 of this document. The key to presenting all credits, public, major, and core, is adequate documentation of the event/activity. Primary documentation is represented by original media: conference programs, testimonial letters from third parties, newspaper clippings, photographs, or video recordings. Please organize documentation materials neatly and present them professionally. Board members reserve the right to accept or reject documentation during program audits.

\section{RE-TESTS}

1. All participants are welcome to re-take any test on which they failed to achieve a passing score. Re-tests will be proctored at the participant's local county Extension office. Contact the MBP board to schedule a re-test. Re-tests are offered at no charge.
2. Re-tests must be taken within a year of the original exam. Those re-tests taken within eight weeks of the original exam will be certified as passing on the original exam date. Those taken more than eight weeks after the original exam date will be certified at the next exam date. This stipulation maintains the prior caveat that each participant must hold each rank for at least one year before being allow to test to advance in the program.

\section{Appendix H \\ Program Awards \\ CATEGORIES}

1. Apprentice Beekeeper of the Year Award (will be awarded to the apprentice who has worked most diligently towards achieving Advanced Beekeeper level)

2. Advanced Beekeeper of the Year Award

3. Master Beekeeper of the Year Award

\section{ELIGIBILITY}

1. Time frame eligible: January 1-December 31 of the current year.

2. Considerations will be given to any active member by January 31 following award year.

3. Must have held respective rank during majority of that calendar year.

For example:

a. If you tested for and advanced to the Advanced Beekeeper level in March, then you would apply for "Advanced Beekeeper of the Year" because you held the advanced level for the majority of the year.

b. However, if you tested for and advanced to the Advanced Beekeeper level in October, then you would apply for "Apprentice Beekeeper of the Year" because you held the apprentice level for the majority of the year.

\section{AWARDS WILL BE BASED ON THE FOLLOWING CRITERIA}

1. Combined average scores on the written and practical examinations taken at each respective level

Once your application is submitted to the HBREL, we will report your scores to the MBP board. 
2. Number of public service credits (PSCs) completed (more is better).

3. Number of necessary requirements exceeded for each level.

4. The total number of people reached through PSCs and other required activities (such as major and core credits, the research project, and/or Extension project).

5. Quality and impact of PSCs and other required activities (such as major and core credits, the research project, and/or Extension program).

Publications, program development work, and other reproducible materials will be generally of greater value to the program than materials designed to benefit only the participant or "one time only" activities the program cannot use again to assist future aspiring beekeepers.

\section{TO BE CONSIDERED}

1. Submit your activity report (see appendix G) to MBP Board.

Awards will be given at the annual UF Bee College Awards Ceremony

\section{Appendix I}

\section{Master Craftsman Research Project or Extension Program Outline}

We suggest the following timeframe to ensure your project is proceeding in a timely manner.

\section{RESEARCH PROJECT}

\section{Year 1:}

1. Choose project focus area and subject (such as pest/ pathogen control [focus area] and small hive beetles [subject]); develop title

2. Literature Review - journals, books, interviews, popular articles

a. What is known about your proposed topic?

b. How have others executed similar projects?

3. Seek and affirm project affiliate (i.e. what institution and individual [advisor] will provide project oversight?)

4. Write a project proposal ( $3-5$ pages at the most)

5. Allow advisor to review proposal
6. Submit proposal to MBP Board - the proposal must be approved by the MBP Board prior to project initiation

7. Collect preliminary data

a. Acquire/construct necessary materials required for project

b. Use proper data collection methods (lab notebook, spreadsheets, etc.)

c. Modify research project based upon preliminary data

8. Review first year's progress with advisor

Year 2:

1. Review project progress with advisor

2. Project execution

a. Data collection

b. Continued literature review: any recently published studies on the topic?

3. Preliminary data analysis - must be approved by MBP Board to proceed

4. Analyze and synthesize the results
a. Photographs
b. Data tables, graphs, and figures
c. Statistical analysis

5. Review project with advisor

6. Prepare final paper, submit to advisor for review
a. Title
b. Abstract
c. Introduction
d. Materials and methods
e. Results
f. Discussion
g. Conclusion
h. Acknowledgments
i. References

7. Project timeline

a. First draft of final paper to be submitted to MBP Board three months before anticipated advancement 
date (MBP exam day). Multiple drafts or edits may be necessary.

b. Oral exam may be scheduled (on exam day - either fall or spring MBP session) once first draft of project report is submitted.

c. Submit final, approved, and edited manuscript to MBP Board on exam day.

d. Thirty-minute oral presentation to of research project be given to the MBP Board with an accompanying slide show on exam day.

\section{EXTENSION PROGRAM}

We require that you identify an individual within your local county Extension office to advise you throughout the project. Extension programs will also require oversight directly from a MBP Board Member. This outline may be modified to suit your individual program.

First six months:

1. Read the following EDIS document on Extension programs
a. "Planning or Refining an Extension Program" http://edis.ifas.ufl.edu/fy1229
b. Program planning overview/review

2. Contact an Extension professional (They will review this outline in detail, prior to project initiation.)

3. Proposal development

a. Determine target audience and their program needs

i. Is your idea something that the target audience needs?

ii. Conduct a needs assessment (e.g. survey)

iii. Read the article "Determine Program Priorities" http://edis.ifas.ufl.edu/wc105

iv. What is your intended participant outcome?

b. Designing your program

i. What is known about your proposed topic?

ii. How have others executed similar programs?

iii. Background research

1. Research literature, documents, popular articles, journals (e.g., The Journal of Extension)

2. Determine local knowledge, identify conflicts and possible barriers, conduct interviews c. Identify networks and partners

i. Who shares your commitment to the program?

ii. Which officials can serve as stakeholders?

iii. Past, current, or potential participants, content experts, staff, volunteers, supervisors, colleagues

d. Review organizational support

e. Determine goals and objectives

i. Specific - Is the objective specific and clear about what will be achieved?

ii. Measurable - Is the objective measurable?

iii. Achievable - Is the objective achievable given the time, resources, and programming?

iv. Relevant - Is the objective relevant and clearly linked to the desired result?

v. Time-Limited - Is the objective stated so it is clear when it will be achieved?

4. Develop educational program, approach, and materials

a. What are your available resources?

b. Are there curricula available already?

c. Do you have funding? Is there funding available?

5. Write program proposal
a. Title
b. Objective
c. Background
d. Program goals
e. Expected outcome
f. Potential impact
g. References

6. Allow advisor to review proposal

a. Submit proposal to MBP Board - the proposal must be approved by the MBP Board before you initiate the project

b. Modify extension program based upon comments from board

Next 12 months:

1. Develop program evaluation

a. "Evaluation Situations, Stakeholders and Strategies" http://edis.ifas.ufl.edu/wc090 
b. Ensure collection of quantitative data

c. Strategy for delivering, collecting, and analyzing evaluations

2. Program implementation
a. Location
b. Logistical support, staffing
c. Advertisement, marketing
d. Financial support
e. Registration
f. Calendar of events

3. Deliver the program

a. Systematically collect feedback and evaluation information

4. Evaluate and analyze report

5. Review program with advisor

Last 6 months

1. Learn, modify, and improve

2. (Re-) Deliver the program

a. Systematically collect feedback and evaluation information

3. Evaluate and analyze report

4. Prepare final paper and submit it to advisor for review
a. Title
b. Abstract
c. Introduction
d. Materials and methods
e. Results
f. Discussion
g. Conclusion
h. Acknowledgments
i. References

5. Project timeline

a. First draft of final paper to be submitted to MBP Board three months before your anticipated advancement date (MBP exam day). Multiple drafts or edits may be necessary. Oral exam may be scheduled (on exam day, either fall or spring MBP session) once first draft of project report is submitted.

b. Submit final approved and edited manuscript to MBP Board on exam day.

c. Thirty-minute oral presentation of research project to be given to the MBP board with an accompanying slideshow on exam day.

\section{University of Florida Master Beekeeper Program Board Members}

Dr. Bill Kern, Department of Entomology and Nematology, University of Florida; whk@ufl.edu

Mr. Ray Zerba, County Extension Agent, Clay County; rzerba@ufl.edu

Dr. Jamie Ellis, Department of Entomology and Nematology, University of Florida; jdellis@ufl.edu

Ms. Jeanette Klopchin, Department of Entomology and Nematology, University of Florida; jklopchin@ufl.edu

Ms. Judy Ludlow, Extension Agent, Calhoun County Extension Service; judy.ludlow@ufl.edu

Mr. Roy Lee Carter, Extension Director, Gulf County Extension Service; rlcarter@ufl.edu

Mrs. Aparna Gazula, Extension Agent, Alachua County Extension Service; agazula@ufl.edu 
Summary of Requirements for the UF Master Beekeeper Program.

\begin{tabular}{|c|c|c|c|c|c|c|c|c|c|}
\hline Level & $\begin{array}{l}\text { Registered } \\
\text { Beekeeper }\end{array}$ & $\begin{array}{c}\text { Written } \\
\text { Exam }\end{array}$ & $\begin{array}{c}\text { Practical } \\
\text { Exam }\end{array}$ & $\begin{array}{l}\text { Oral } \\
\text { Exam }\end{array}$ & Modules & $\begin{array}{l}\text { Public } \\
\text { Service } \\
\text { Credits }\end{array}$ & Core Credits & $\begin{array}{l}\text { Major } \\
\text { Credits }\end{array}$ & $\begin{array}{c}\text { Research/ } \\
\text { Extension } \\
\text { Program }\end{array}$ \\
\hline Apprentice & $x$ & $x$ & $x$ & - & - & - & - & - & - \\
\hline Advanced & $x$ & $x$ & $x$ & - & $x(6)$ & 5 & - & $-*$ & - \\
\hline Master & $x$ & $x$ & - & - & - & 10 & 5 & 3 & $\begin{array}{l}\mathrm{x} \text { (project } \\
\text { approval) }\end{array}$ \\
\hline $\begin{array}{l}\text { Master } \\
\text { Craftsman }\end{array}$ & $x$ & - & - & $x$ & - & 15 & 8 & 5 & $x$ \\
\hline $\begin{array}{l}\text { Credit } \\
\text { totals }\end{array}$ & - & - & - & - & - & $\begin{array}{c}30 \\
\text { (minimum) }\end{array}$ & $13^{* *}$ & $8^{* *}$ & - \\
\hline
\end{tabular}




\section{UF $\mid$ IFAS Extension \\ UNIVERSITY of FLORIDA}

Level of Program Testing for:

(Advanced, Master, Master Craftsman)

Candidate should retain completed form to turn in on day of exam.

\section{Documentation of Public Service Credits}

\section{UNIVERSITY OF FLORIDA MASTER BEEKEEPER PROGRAM}

(to be completed with assistance from Master Beekeeper Program candidate and signed by representative from organization sponsoring/hosting the event)

On this date: , (name) a candidate for the University of Florida's Master Beekeeper Program, provided or completed an act of public service, which covered the following subject matter related to beekeeping, honey bee pollination, or honey production:

\section{(Please circle applicable areas)}

1. Presenting bee-related lecture or workshop to nonbeekeeping group

2. Holding office in a local beekeeping association

3. Assisting members of youth organizations with project work

4. Mentoring a new beekeeper through at least one complete season

Other:

Organization name:

Name of event: Date:

General description of event:

Estimated number of participants/attendees:

Printed name/title of representative/witness:

Signature of representative/witness:

Contact information (phone and/or email) for signee:
5. Presenting a public demonstration on beekeeping topic at fair, festival or similar public event

6. Providing a hive of bees to pollinate a public garden

7. Establishing and maintaining an observation hive for school or civic group

8. Becoming an expert contact on bee-related questions for a UF/IFAS Extension County office (please see Appendix A) 


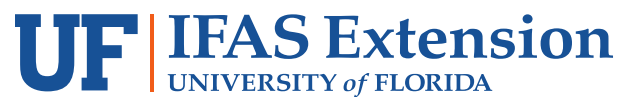

\section{Major Declaration Form}

\section{UNIVERSITY OF FLORIDA MASTER BEEKEEPER PROGRAM}

Name:

Address:

E-mail address:

Phone \#:

For the following, please only choose $\mathbf{1}$. Clearly mark your selection below:

Diagnosis and Treatment of Honey Bee Pests, Parasites, and Pathogens

Pollination Ecology and Bee Botany

Honey Judging

Beekeeping for International /Rural Development

Queen Production

Africanized Honey Bees

Advanced Bee Husbandry

Native Bee Apiculture

Apiculture Education

I would like to propose my own major and will contact the Master Beekeeper Board for approval. My proposed major is

$\mathrm{I}$, , have chosen a major as indicated above. Should I choose to change my major, I will promptly contact the board at honeybee@ifas.ufl.edu and resubmit my form. 


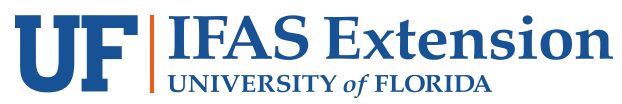

Level of Program Testing for:

(Advanced, Master, Master Craftsman)

Candidate should retain completed form to turn in on day of exam.

\section{Documentation of Core/Major Credits}

\section{UNIVERSITY OF FLORIDA MASTER BEEKEEPER PROGRAM}

(to be completed with assistance from Master Beekeeper Program candidate and signed by representative from organization sponsoring/hosting the event)

On this date(s): , (name) , a candidate for advancement in the University of Florida's Master Beekeeper Program, provided or completed a service/duty/act which qualifies as a core or major credit as outlined in the MBP Manual (Appendix B or C). The service covered the following subject matter related to beekeeping, apiculture, education, agriculture or other relevant topic as outlined in the MBP Manual:

Major Credit / Core Credit (circle one)

Please list Appendix, relevant subheadings, and credit description (as written in the manual): I.e.: Appendix C: 2:Pollination Ecology and Bee Botany; J: create museum-quality plant collection of regional honey plants.

Description of specific action taken to earn credit:

Relevant quantification: (i.e., number of hours, people, publications, etc. your activity reached.)

Printed name \& title of representative/witness:

Signature of representative/witness:

Contact information (phone and/or email) for signee: 


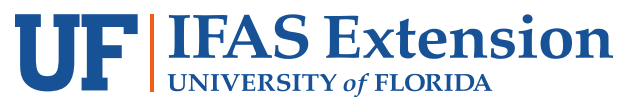

\section{Advanced Level Cover Sheet}

\section{UNIVERSITY OF FLORIDA MASTER BEEKEEPER PROGRAM}

Date Apprentice Level Achieved:

$$
\text { Month/Year }
$$

\section{PUBLIC SERVICE CREDITS}

Please use a few words to describe the event, the date it occurred and the number of people reached for each of the 5 credits. There is space provided to list credits achieved above the required minimum. If necessary, please list any additional credits on another sheet of paper.

\begin{tabular}{|l|l|l|}
\hline Description of Public Service Credit & Date & \# people reached \\
\hline 1. & & \\
\hline 2. & & \\
\hline 3. & & \\
\hline 4. & & \\
\hline 5. & & \\
\hline 6. & & \\
\hline 7. & & \\
\hline 8. & & \\
\hline 9. & & \\
\hline 10. & & \\
\hline
\end{tabular}

Please sign and date below to certify that all of the above information is correct and accurate to the best of your knowledge. 


\section{UF $\mid$ IFAS Extension

Last Name

First Name

\section{Master Level Cover Sheet - UNIVERSITY OF FLORIDA MASTER BEEKEEPER PROGRAM}

Date Apprentice Level Achieved:

$$
\text { Month/Year }
$$

Date Advanced Level Achieved:

$$
\text { Month/Year }
$$

\section{PUBLIC SERVICE CREDITS}

Please use a few words to describe the event, the date it occurred and the number of people reached for each of the 10 credits. Please list additional credits (those above the required 10) on another sheet of paper.

\begin{tabular}{|l|l|l|}
\hline Description of Public Service Credit & Date & \# people reached \\
\hline 1. & & \\
\hline 2. & & \\
\hline 3. & & \\
\hline 4. & & \\
\hline 5. & & \\
\hline 6. & & \\
\hline 7. & & \\
\hline 8. & & \\
\hline 9. & & \\
\hline 10. & & \\
\hline
\end{tabular}

\section{MAJOR CREDITS}

DECLARED MAJOR:

\begin{tabular}{|l|l|l|}
\hline Description of Major Credit & Date & \# people reached \\
\hline 1. & & \\
\hline 2. & & \\
\hline 3. & & \\
\hline
\end{tabular}

\section{CORE CREDITS}

\begin{tabular}{|l|l|l|}
\hline Description of Core Credit & Date & \# people reached \\
\hline 1. & & \\
\hline 2. & & \\
\hline 3. & & \\
\hline 4. & & \\
\hline 5. & & \\
\hline
\end{tabular}

Please sign and date below to certify that all of the above information is correct and accurate to the best of your knowledge. 


\section{UF $\mid$ IFAS Extension

\section{Master Craftsman Level Cover Sheet - UNIVERSITY OF FLORIDA MASTER BEEKEEPER PROGRAM}

Date Apprentice Level Achieved:

$$
\text { Month/Year }
$$

Date Advanced Level Achieved:

$$
\text { Month/Year }
$$

Date Master Level Achieved:

$$
\text { Month/Year }
$$

\section{PUBLIC SERVICE CREDITS}

Please use a few words to describe the event, the date it occurred and the number of people reached for each of the 15 credits. Please list additional credits (those above the required 15) on another sheet of paper.

\begin{tabular}{|l|l|l|}
\hline Description of Public Service Credit & Date & \# people reached \\
\hline 1. & & \\
\hline 2. & & \\
\hline 3. & & \\
\hline 4. & & \\
\hline 5. & & \\
\hline 6. & & \\
\hline 7. & & \\
\hline 8. & & \\
\hline 9. & & \\
\hline 10. & & \\
\hline 11. & & \\
\hline 12. & & \\
\hline 13. & & \\
\hline 14. & & \\
\hline 15. & & \\
\hline
\end{tabular}

\section{MAJOR CREDITS}

\section{Description of Major Credit}

1.

2.

3.

4.

5.

2.

3.

\section{DECLARED MAJOR:}

\begin{tabular}{|l|l|l|} 
& Date & \# people reached \\
\hline & & \\
\hline
\end{tabular}


Master Craftsman Form cont....

\section{CORE CREDITS}

\begin{tabular}{|l|l|l|}
\hline Description of Core Credit & Date & \# people reached \\
\hline 1. & & \\
\hline 2. & & \\
\hline 3. & & \\
\hline 4. & & \\
\hline 5. & & \\
\hline 6. & & \\
\hline 7. & & \\
\hline 8. & & \\
\hline
\end{tabular}

\section{COMMUNICATION SKILLS}

\begin{tabular}{|l|l|l|}
\hline Program/Interview/Article Name & $\begin{array}{l}\text { Affiliation (TV station name, } \\
\text { newspaper title etc) }\end{array}$ & \\
\hline 1. & Date & \\
\hline 2. & & \\
\hline
\end{tabular}

\section{RESEARCH/EXTENSION PROJECT}

\begin{tabular}{|l|l|l|}
\hline Project title & Affiliation (UF, FDACS, etc) & Dates (begin/end) \\
\hline & & \\
\end{tabular}

Oral Examination Score

Please do not mark this area, for MBP Board use only

Please sign and date below to certify that all of the above information is correct and accurate to the best of your knowledge. 